admitted to the United Kingdom by the Home Office as refugees and who havo been allowed to enter into employment as domestic servants in private households. The Government policy of locating new factories and other establishments required in connexion with the defence programme in areas of heavy unemployment, so far as strategic and other practical considerations allow, has led during the year to the setting up of new establishments employing many thousands of workers in the Special Areas and in other areas of heavy unemployment. With regard to juvenile employment, the report points out that the estimated number of juveniles aged 14-17 avail. able for employment was about 159,000 less than at the end of 1937. The numbers aged 14 entering the industrial field have been decreasing since. 1931, and by 1934 the decline in the birth-rate after 1920 had influenced the numbers in the whole 14-17 group. Although prospects of employment for juveniles remained fairly good in most parts of Great Britain, they were less bright than in 1937.

\section{British Trust for Ornithology}

THE fifth annual report of the British Trust for Ornithology reveals the remarkable progress made in the co-ordination of field studies in Britain in recent years, and much space is given to the results of these field investigations. Thoy includo the lapwing habitat inquiry, and that of the distribution of the corncrake, which is to be continued this year. In 1938, 1200 completed returns were received referring to the corncrake and noting its decreasing numbers, most marked in Ireland and least in Scotland; efforts are being made to get information from the Continent, where the species is also decreasing. Tho survey of black-headed gull colonies had 150 observers, and shors that few coastal counties have been colonized in the past twenty-five years, but there has been a marked inland spread. The sample census of heronries shows an increase of breeding stock in many places, and three heronries in England now have between 120 and 150 nests. Tho bridled guillemot inquiry shows that few of this variety are in the English and Welsh colonies, but the percentage increases from about lat. $56^{\circ} \mathrm{N}$. The woodeock inquiry showed by ringing that occasional British woodcock accompany the winter migrants when they return to their native breeding haunts. The woodland bird inquiry gave special attention to the British sub-species of birds, which can bo divided into four groups showing thirty-seven distinctive races of bird entirely confined to Britain. A now inquiry on the redshank is planned for 1939-40 and a hatching and fledging inquiry will extend nationally the work started at Whipsnade Bird Sanctuary.

\section{Tuberculin Tests in Cattle}

Borise tuberculosis is one of the most serious scourges that afficts cattle in Great Britain, causing an annual loss which has been estimated to amount to $£ 2,000,000$ annually. The disease in dairy herds is also responsible for much human tuberculosis, particularly in children. The eradication of tuber- culosis from herds is now receiving serious attention. The detection of tuberculous animals by means of the tuberculin test is employed in all schemes for the eradication of bovine tuberculosis, but in recent years modifications in methods of preparation of tuberculin and in its application have been introduced. The need for detailed research into various problems associated with the tuberculin test was recognized by the Joint Tuberculosis Committee of the Medical Research and Agricultural Research Councils, and work on the subject was undertaken at the Institute of Animal Pathology, Cambridge, by Prof. J. B. Buxton and Mrr. R. E. Glover, and the results of their investigations are published in a report issued by the Agricultural Research Council ("Tuberculin Tests in Cattle". H.Mr. Stationery Office. $1 s .6 d$. net). After dealing with the different methods of applying the tuberculin test, sections are devoted to the value of several types of tuberculin, sensitization and desensitization of tuberculous and non-tuberculous cattle to tuberculin, and the possibility of 'doping' against the various tests. Experi. ments are also described in which attempts were made to sensitize normal cattle to tuberculin itself, and finally, the significance of reactions, resulting from infections with organisms closely allied to the bovino tubercle bacillus, is discussed.

\section{University of London: Principal's Report}

Is recent years a corporato university spirit has made itself increasingly felt in London. Its growth has, naturally, been stimulated by the erection of the imposing block of central buildings in Bloomsbury and the grouping there in association with them of several important schools and institutes. It will receive a further notable impulse from the opening of the new Students' Union. The Union has already proved its value as a centre of student life, and Lord Nuffield's gift last year of $\mathfrak{5} 50,000$, added to a grant of $£ 25,000$ from the National Fitness Council and one of $£ 35,000$ from the University Grants Committee, has enabled the Court to proceed to the construction and equipment on a generous scale of a permanent home for it. Among other interesting items of the Principal's report may be mentioned: a closer association with external students through a new system of communicating detailed examination results to all Intermediate Examination candidates and to the institutions responsible for their training; a new Certificate in Natural History for prospective teachers of nature study in primary schools; and the estab. lishment of an editorial board under the chairmanship of Sir Bernard Pares, who is retiring from the directorship of the School of Slavonic and East European Studies, to be responsible for the publication of the Slaronic and East European Review.

\section{New Entomological Journals}

Tre Entomological Society of Southern Africa was founded in 1937 and the first volume of its Journal, dated March 30,1939, has come to hand. It contains seven papers, covering a very wide range of subjects, including taxonomic studies on Diptera 